\title{
THE TWIN DEFICITS PROBLEM IN INDIA
}

\author{
Özgür Bayram Soylu ${ }^{146}$
}

https://doi.org/10.31410/itema.2018.348

\begin{abstract}
The main aim of this paper is to investigate the twin deficit problem for the Indian economy using Granger Causality Test for the period 1988-2017. The co-integration analysis shows that there is a long run relation between budget deficit and current account balance. Despite the high savings rates, the twin deficits are valid for the Indian economy. The direction of the relationship is budget deficit to current account balance according to Granger Causality Test results. This result is consistent with the traditional Keynesian twin deficit hypothesis.
\end{abstract}

Keywords: Budget Deficit, Current Account Balance, Twin Deficits, Granger Causality.

\section{INTRODUCTION}

$\mathrm{T}$ win deficit hypothesis suggests that there is a positive and strong causality relationship between the current account deficit and the budget deficit (Parkin, 2000, p.848). In other words, the budget deficit by the increase in government expenditures is called the twin deficit, which affects the balance of current accounts negatively. In the early 1980s, the United States faced a major budget deficit problem. This budget deficit has led to a decline in economic activity. In the following process, budget deficits were also accompanied by high deficits in the balance of current account. This situation initiated the "twin deficit" debate, which expresses the relationship between the two deficits, and the relationship between the two deficits has become an important issue of economic policies (Khalid and Guan, 1999: 389). The debt crisis that emerged in developed countries following the 2008 global financial crisis, which has deeply affected the world, has led to a re-questioning of the budget and current account deficit relationship in many countries. It is important to know the direction of budget and current account balance deficits relation in terms of finding a solution to the twin deficit problem.

The budget deficits lead to current account deficits, and these two deficits appear at the same time according to twin deficit hypothesis. In a sense, the twin deficit hypothesis represents the collective action of budget deficits and current account deficits.

Budget deficits and current account deficits, which are the main indicators of economic policies, are chronic problems in many developed and developing countries.

One of the most fundamental economic problems facing most developing countries is the current account deficit and the choice of policy to be implemented to address this deficit (Bayraktutan and Demirtaş, 2011). The changes in the current account are evaluated as a signal for the course of the economy and therefore play a decisive role in shaping economic decisions and expectations (Erdoğanand Bozkurt, 2009).

\footnotetext{
${ }^{146}$ Kocaeli University/Faculty of Economics and Administrative Sciences/Department of Economics/Department of Policy of Economics, Kocaeli/Turkey
} 
The main aim of this paper is to test the twin deficit hypothesis by Granger Causality for Indian economy for the period 1988-2017. The remaining part of the paper is arranged as follows. In the first part, the theoretical structure of the relationship between budget deficits and current account deficits is given. In the second part, the literature review is given. In the third part, data set and empirical application are given. In the last part of the paper, the results are discussed.

\section{THEORETICAL FRAMEWORK}

The relationship between budget deficit and current account deficits is dealt with as the Traditional Keynesian Approach, the Ricardian Equivalence Approach, and the Neo-Classical Approach. While there is a positive relationship between budget deficit and current transactions in the Keynesian approach, there is no relation between budget deficit and current account deficit in the Ricardian Equivalence hypothesis. Monetarists argue that there is a positive relationship between budget deficits and current account deficits. The neo-classical approach defends the idea that long-term permanent budget deficits affect economic variables rather than temporary budget deficits.

Relations between budget deficits and current account deficits in open economies are shown to depend on national income equality. National income equality; (Krugman and Obstfeld, 2006: pp.285-291).

$Y=C+I+G+(X-M)$

$Y-(C+I+G)=C A B$

$\mathrm{Y}$ refers to national income, $\mathrm{C}$ refers to private consumption expenditure, $\mathrm{G}$ refers to government expenditure and also $(\mathrm{C}+\mathrm{I}+\mathrm{G})$ represents total expenditure, $\mathrm{X}$ refers to export and $\mathrm{M}$ refers to import. Net exports (X-M) represent current account balance (CAB).

$\mathrm{S}$ represents savings in closed economy assumptions. Given that savings are equal to investments, $\mathrm{S}=\mathrm{I}$, it is obtained by subtracting national consumption expenditures from national income $(\mathrm{Y}-\mathrm{C}=\mathrm{S})$.

In the open economy, $(\mathrm{S})$, national saving is equal to the unconsumed part of the national income both of private consumption and government expenditure.

$$
\begin{aligned}
& S=Y-C-G \\
& I=Y-C-G
\end{aligned}
$$

(S) National saving equation is:

$$
S=I+C A B
$$

Total savings is the sum of private sector savings ( $\mathrm{Sp}$ ) and government sector savings ( $\mathrm{Sg}$ ).

$$
S=S p+S g
$$

Private sector savings $(\mathrm{Sp})$ refer to the part of the after-tax income that is not consumed.

$S p=Y-T-C$ 
Government sector savings ( $\mathrm{Sg}$ ) show the difference between the net tax revenue generated by the government sector and government expenditures.

$S g=T-G$

When the national saving function is regulated in the light of all these definitions,

$S=Y-C-G=(Y-T-C)+(T-G)=S p+S g$

For open economies,

$$
\begin{aligned}
& S=I+C A B=S p+S g \\
& S p=I+C A B-S g=I+C A B-(T-G)=I+C A B+(G-T) \\
& C A B=S p-I-(G-T) \\
& C A B=(S p-I)-(G-T)
\end{aligned}
$$

$C A B$ represents current account balance, $(S p-I)$; it represents the difference between private savings and private investments.

If the gap between private investments and private savings is stable, any increase in budget deficits leads to an increase in current account deficits. This interaction leads to the twin deficit (Erdinç, 2008).

\section{LITERATURE REVIEW}

The relationship between budget deficit and current account deficit has been addressed in many scientific studies. Studies in the economic literature related to the effects of budget deficits have shown different results for different periods in different countries by different researchers using different models and methods. But it cannot be said that a common consensus has been reached in these studies. The studies that test the relation between budget deficit and current account deficit are considered chronologically in table 1.

Table1: Literature Review

\begin{tabular}{|l|l|l|l|l|}
\hline Study & Sample & Period & Methodology & Main Finding \\
\hline Darrat (1988) & U.S. & $1960-1984$ & Granger Casuality & Bidirectional relation \\
\hline Haug (1990) & U.S. & $1929-1985$ & Granger Casuality & No relation \\
\hline $\begin{array}{l}\text { Zietz and Pemberton } \\
\text { (1990). }\end{array}$ & U.S & $1972-1987$ & OLS Regression & BD to CAB \\
\hline Bachman (1992) & U.S. & $1974-1988$ & Bivariate VARs. & $\begin{array}{l}\text { The U.S. must reduce the } \\
\text { Federal budget deficit to } \\
\text { eliminate its current } \\
\text { account deficit. }\end{array}$ \\
\hline Winner (1993) & Australia & $1983-1989$ & $\begin{array}{l}\text { Regression } \\
\text { analysis }\end{array}$ & $\begin{array}{l}\text { Theorem supports the } \\
\text { movements in the } \\
\text { economy }\end{array}$ \\
\hline
\end{tabular}




\begin{tabular}{|c|c|c|c|c|}
\hline Vamyoukas (1999) & Greece & 1948-1994 & $\begin{array}{lr}\text { Error } & \text { Correction } \\
\text { Model } & \text { and } \\
\text { Granger Causality }\end{array}$ & $\begin{array}{l}\text { Unidirectional relation, } \\
\text { budget deficit to trade } \\
\text { deficit. }\end{array}$ \\
\hline $\begin{array}{l}\text { Akbostanc1 and Tunç } \\
(2002)\end{array}$ & Turkey & $1987-2001$ & $\begin{array}{l}\text { Error Correction } \\
\text { Model }\end{array}$ & $\begin{array}{l}\text { There is a long-run } \\
\text { relationship between the } \\
\text { two deficits. }\end{array}$ \\
\hline Kaufmann et.al (2002) & Austria & 1976-1988 & VAR & $\begin{array}{lll}\text { Budget deficits } & \text { do not } \\
\text { affect current } & \text { account } \\
\text { deficits. } & & \end{array}$ \\
\hline Kouassi et.al. (2004) & $\begin{array}{l}\text { Twenty } \\
\text { developed } \\
\text { and } \\
\text { developing } \\
\text { countries }\end{array}$ & $1950-1988$ & Granger Causality & $\begin{array}{lll}\text { Unidirectional or } & \text { bi- } \\
\text { directional relation. } & \text { for } \\
\text { developed } & & \\
\text { countries } & \text { are } & \text { less } \\
\text { persuasive } & & \\
\end{array}$ \\
\hline Pattichis (2004) & Lebanon & $1982-1987$ & $\begin{array}{l}\text { Error Correction } \\
\text { Model }\end{array}$ & $\begin{array}{l}\text { Unidirectional relation, } \\
\text { budget deficit to trade } \\
\text { deficit. }\end{array}$ \\
\hline $\begin{array}{l}\text { Baharumshah et.al. } \\
\text { (2006) }\end{array}$ & ASEAN & $1976-2000$ & Granger Causality & Bidirectional relation \\
\hline Kim and Kim (2006) & Korea & $1970-2003$ & $\begin{array}{l}\text { Modified Wald } \\
\text { Test }\end{array}$ & $\mathrm{CAB}$ to $\mathrm{BD}$. \\
\hline Ganchev et.al (2012) & $\begin{array}{l}\text { CEE } \\
\text { countries }\end{array}$ & 1998-2009 & $\begin{array}{l}\text { OLS Panel } \\
\text { Regression }\end{array}$ & $\begin{array}{l}\text { Twin deficit rejected in the } \\
\text { case of Bulgaria and } \\
\text { Estonia. }\end{array}$ \\
\hline $\begin{array}{l}\text { Kalou and Paleologou } \\
\text { (2012) }\end{array}$ & Greece & $1960-2007$ & VECM & $\mathrm{CAB}$ to $\mathrm{BD}$ \\
\hline $\begin{array}{l}\text { Perera and Liyanage } \\
(2012) \text {. }\end{array}$ & Sri Lanka & 1960-2009 & Granger Casuality & Unidirectional relation \\
\hline $\begin{array}{l}\text { Chihi and Normandin } \\
\text { (2013) }\end{array}$ & $\begin{array}{l}\text { Selected } \\
\text { developing } \\
\text { countries }\end{array}$ & $\begin{array}{l}\text { From } 1960 \\
\text { onwards }\end{array}$ & $\begin{array}{l}\text { Generalized } \\
\text { Methods } \\
\text { Moments }\end{array}$ & $\begin{array}{l}\text { the positive and } \\
\text { statistically significant } \\
\text { covariance between fiscal } \\
\text { deficit and current account } \\
\text { deficit }\end{array}$ \\
\hline $\begin{array}{l}\text { Trachanas and } \\
\text { Katrakilidis (2013). }\end{array}$ & $\begin{array}{l}\text { Five } \\
\text { European } \\
\text { economies }\end{array}$ & $1971-2009$ & $\begin{array}{l}\text { The asymmetric } \\
\text { co-integration } \\
\text { methodology }\end{array}$ & $\begin{array}{l}\text { direct long-run connection } \\
\text { between the two deficits }\end{array}$ \\
\hline Xie and Chen (2014) & $\begin{array}{l}\text { Eleven } \\
\text { OECD } \\
\text { countries }\end{array}$ & $1980-2010$ & $\begin{array}{l}\text { Panel Granger } \\
\text { Causality }\end{array}$ & $\begin{array}{l}\text { No relation for UK and } \\
\text { France. } \\
\text { BD to CAB for Norway } \\
\text { and Switzerland. } \\
\text { The current account } \\
\text { targeting hypothesis valid } \\
\text { for Ireland, Spain and } \\
\text { Sweden } \\
\text { Bidirectional causality for } \\
\text { Belgium, Finland, Greece } \\
\text { and Iceland. }\end{array}$ \\
\hline $\begin{array}{l}\text { Ravinthirakumaran, } \\
\text { et.al.(2016). }\end{array}$ & $\begin{array}{l}\text { Five } \\
\text { SAARC } \\
\text { countries }\end{array}$ & $1980-2012$ & Granger Causality & $\begin{array}{l}\text { BD to CAB in Pakistan and } \\
\text { Sri Lanka } \\
\text { CAB to BD in India and } \\
\text { Nepal } \\
\text { Short run causality CAB to } \\
\text { BD in Bangladesh. }\end{array}$ \\
\hline
\end{tabular}




\begin{tabular}{|l|l|l|l|l|}
\hline $\begin{array}{l}\text { Bhat and Sharma } \\
(2018)\end{array}$ & India & 1970-2016 & Non-linear ARDL & $\begin{array}{l}\text { therefore refutes the } \\
\text { Ricardian Equivalence } \\
\text { proposition and validates } \\
\text { the twin-deficit hypothesis }\end{array}$ \\
\hline Helmy (2018) & Egypt & $1975-2014$ & VAR-VECM & $\begin{array}{l}\text { CAB to BD in short-term } \\
\text { according to VAR results, } \\
\text { refutes the twin deficit } \\
\text { hypothesis in favor of the } \\
\text { currentaccount targeting } \\
\text { hypothesis according to } \\
\text { VECM }\end{array}$ \\
\hline Mohanty (2018) & India & $1970-2014$ & ARDL & $\begin{array}{l}\text { The results support the } \\
\text { validity of twin deficits } \\
\text { hypothesis. }\end{array}$ \\
\hline $\begin{array}{l}\text { Turan and Karakaş } \\
(2018) .\end{array}$ & $\begin{array}{l}\text { CEE } \\
\text { Countries }\end{array}$ & 1996-2016 & NARDL & $\begin{array}{l}\text { CAB to BD in Poland and } \\
\text { Romania in the long-run } \\
\text { and Croatia, Poland, } \\
\text { Romania and Slovakia in } \\
\text { the short-run } \\
\text { BD to CAB in Czech } \\
\text { Republic, Hungary, and } \\
\text { Slovakia in the long-run } \\
\text { and in Czech Republic, } \\
\text { Hungary, Slovakia, and } \\
\text { Romania in the short-run. }\end{array}$ \\
\hline
\end{tabular}

The results of the studies can be summarized as follows:

$>$ There is a unidirectional relationship between current account deficit and budget deficit,

$>$ There is a bidirectional relationship between current account deficit and budget deficit,

$>$ There is no relationship between current account deficit and budget deficit.

\section{DATA AND METHODOLOGY}

In the study, the twin deficits hypothesis was examined for the period 1988-2017 for Indian economy. The data set was taken from International Monetary Fund (IMF World Economic Outlook). The basic model equation is as follows:

$C A B=\alpha 0+\alpha 1 B D+\mu t$

$C A B$ refers to Current Account Balance, BD refers to Budget Deficit and $\mu$ t is the error term. Figure 1 reflects the current account balance, budget deficit and savings of Indian economy. Despite the high savings rates, the twin deficits of the Indian economy are remarkable. The horizontal axis represents years and vertical axis represents rates of selected indicators. 
Figure 1: Current Account Balance, Budget Deficit and Savings of Indian Economy

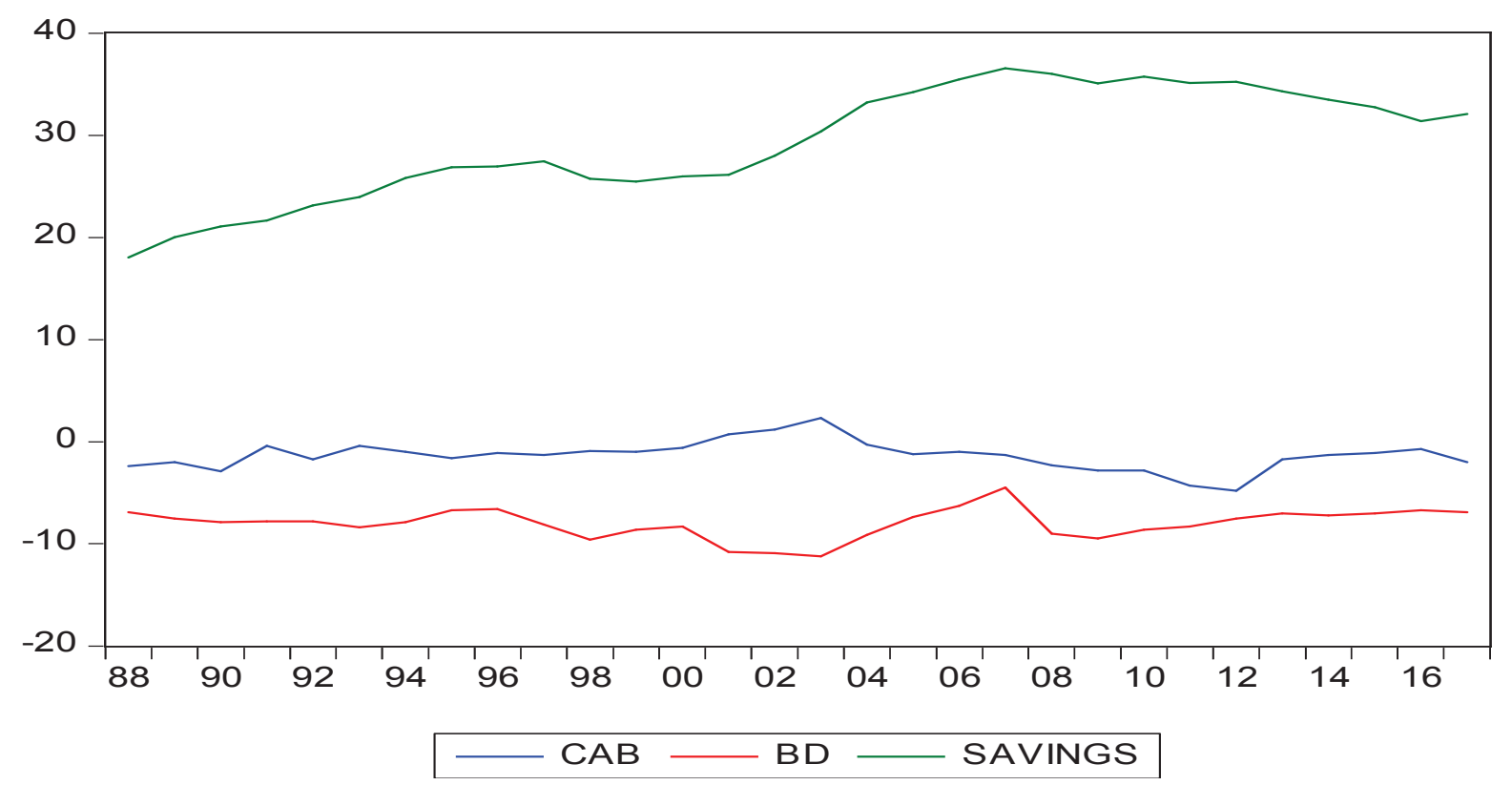

The time series approach is used as the econometric method in this study. Firstly, the stationary of the variables was tested using the ADF test. Secondly, the existence of co-integration is tested for variables. As a final step, the Granger causality test was used to determine the direction of the relation.

\section{EMPRICAL FINDINGS AND DISCUSSION}

The stationary is more important in the time series analysis. Augmented Dickey Fuller (ADF) test is the most commonly used unit root test. The Augmented Dickey Fuller (ADF) unit root test is used to determine whether the variables are stationary or not.

Table 2 reflects the results of unit root tests for current account balance (CAB, $\%$ of GDP) and budget deficit (BD, \% of GDP).

Table 2. Unit Root Test Results (at Level)

\begin{tabular}{|l|c|c|}
\hline & CAB & BD \\
\hline t-statistic & -2.447004 & -2.657566 \\
\hline Probability & 0.3498 & 0.2599 \\
\hline $\begin{array}{l}\text { Critical } \\
\text { Values }\end{array}$ & \\
\hline $1 \%$ & -4.309824 & -4.309824 \\
\hline $5 \%$ & -3.574244 & -3.574244 \\
\hline $10 \%$ & -3.221728 & -3.221728 \\
\hline $\mathrm{H}_{0}=\mathrm{CAB}$ has a unit root & \\
$\mathrm{H}_{2}=\mathrm{BD}$ has a unit root. & \\
* The $\mathrm{H}_{0}$ and $\mathrm{H}_{2}$ hypothesis are accepted because the probability value is bigger than 0.05, the \\
series is not stationary. \\
Source: Calculated by Eviews
\end{tabular}


Table 2 shows that the current account balance and budget deficit series are not stationary at level. The first differences of these two series have been taken to stationary. Table 3 reflects the results of unit roots for current account balance and budget deficit series at first differences.

Table 3. Unit Root Test Results (at First Differences)

\begin{tabular}{|c|c|c|}
\hline & CAB & BD \\
\hline t-statistic & -5.913392 & -4.810632 \\
\hline Probability & 0.0002 & 0.0032 \\
\hline \multicolumn{3}{|c|}{ Critical Values } \\
\hline $1 \%$ & -4.323979 & 4.323979 \\
\hline $5 \%$ & -3.580623 & -3.580623 \\
\hline $10 \%$ & -3.225334 & -3.225334 \\
\hline \multicolumn{3}{|c|}{$\begin{array}{l}\mathrm{H}_{0}=\mathrm{CAB} \text { has a unit root } \\
\mathrm{H}_{2}=\text { BD has a unit root } \\
* \text { The } \mathrm{H}_{0} \text { and } \mathrm{H}_{2} \text { hypothesis are rejected because the probability value is smaller than } 0.05 \text {, the } \\
\text { series is stationary. } \\
\text { Source: Calculated by Eviews }\end{array}$} \\
\hline
\end{tabular}

The Johansen co-integration test is useful for check existence of long run relationship between current account balance and budget deficit. The first step of the Johansen co-integration test is to determine the appropriate lag length. Critical values such as Akaike, Schwarz and HannanQuinn are used to determine the lag length. The lag length providing the smallest critical value is determined as the lag length of the model. The optimal lag length was determined as 5 based on AIC.

The results of Johansen co-integration test is shown in table 4. It is understood that there is cointegration relationship between current account balance budget deficits. Trace test indicates two co-integrating eqn(s) at the 0.05 level and maximum Eigen value test indicates two cointegrating eqn(s) at the 0.05 level.

Table 4: Johansen Co-integration Test Results

\begin{tabular}{|c|c|c|c|c|}
\hline Hypothesized no. of CE(s) & Eigen value & Trace statistic & 0.05 critical value & Prob. \\
\hline \multicolumn{5}{|c|}{ Unrestricted co-integration rank test (trace) } \\
\hline None & 0.583137 & 28.18860 & 12.32090 & 0.0001 \\
\hline At most 1 & 0.295730 & 8.063655 & 4.129906 & 0.0054 \\
\hline Hypothesized no. of CE(s) & Eigen value & Max-Eigen statistic & 0,05 critical value & Prob. \\
\hline \multicolumn{5}{|c|}{ Unrestricted co-integration rank test (maximum Eigen value) } \\
\hline None & 0.583137 & 20.12494 & 11.22480 & 0.0011 \\
\hline At most 1 & 0.295730 & 8.063655 & 4.129906 & 0.0054 \\
\hline
\end{tabular}

The Granger Causality test is based on testing the significance of the lagged values of the independent variable in the regression equation (Granger, 1969, pp.424-438). The Granger Causality test was used to determine the direction of causality between the budget deficits and the current account deficit. The variables have to be stationary in order to applying Granger causality test. As mentioned above, it is reached that stationary at first differences by using ADF test. In table 5, the results of Granger Causality test are shown. The direction of the relationship is budget deficit to current account balance. In other words budget deficit does cause current account deficits for Indian Economy 
Table 5: Granger Causality Test Results

\begin{tabular}{lcc}
\hline Dependent variable: CAB(-1) & & \\
\hline Excluded & Chi-sq & \multicolumn{1}{c}{ Prob. } \\
BD(-1) & 16.70660 & 0.0051 \\
All & 16.70660 & 0.0051 \\
\hline & & \\
\hline Dependent variable: BD(-1) & & \\
Excluded & Chi-sq & Prob. \\
CAB(-1) & 2.716582 & 0.7436 \\
All & 2.716582 & 0.7436 \\
\hline
\end{tabular}

\section{CONCLUSION}

The budget deficit and current account deficit is observed in Indian economy for many years. The twin deficit hypothesis is investigated using co-integration analysis and Granger causality test for 1988-2017 period with annual data. The direction of causality between budget deficits and current account deficit was examined using Johansen co-integration analysis and Granger Causality test. It is concluded that there is a long-run relationship between budget deficit and current account deficit. This result is consistent with the traditional Keynesian twin deficit hypothesis. In addition, the direction of the relationship is budget deficit to current account balance. In other words budget deficit does cause current account deficits for Indian Economy.

Despite the high savings rates, the twin deficits are valid for the Indian economy. This finding is remarkable. The results of the analysis show that the main economic problem is budget deficits for Indian economy. Policy makers should develop policies to budget balance. This will also have positive effects on the current account balance.

\section{REFERENCES}

[1]. Akbostanci, E. \& Tunç, G. İ. (2001). Turkish twin effects: An error correction model of trade balance (No. 0106). ERC-Economic Research Center, Middle East Technical University.

[2]. Bachman, D. D. (1992). Why is the US current account deficit so large? Evidence from vector auto regressions. Southern Economic Journal, 232-240.

[3]. Baharumshah, A. Z. Lau, E. \& Khalid, A. M. (2006). Testing twin deficits hypothesis using VARs and variance decomposition. Journal of the Asia Pacific economy, 11(3), 331-354.

[4]. Bayraktutan, Y. \& Demirtaş, I. (2011). Gelişmekte Olan Ülkelerde Cari Açiğin Belirleyicileri: Panel Veri Analizi. Kocaeli Üniversitesi Sosyal Bilimler Enstitüsü Dergisi, (22), 1-28.

[5]. Bhat, J. A. \& Sharma, N. K. (2018). The twin-deficit hypothesis: revisiting Indian economy in a nonlinear framework. Journal of Financial Economic Policy.

[6]. Chihi, F. \& Normandin, M. (2013). External and budget deficits in some developing countries. Journal of International Money and Finance, 32, 77-98.

[7]. Darrat, A. F. (1988). Have large budget deficits caused rising trade deficits?. Southern Economic Journal, 879-887.

[8]. Erdinç, Z. (2008). İkiz Açıklar Hipotezinin Türkiye'de 1950-2005 Yı1ları Arasında Eş Bütünleşme Analizi Ve Granger Nedensellik Testi İle İncelenmesi.

[9]. Erdoğan, S. \& Bozkurt, H. (2009). Türkiye'de cari açı̆̆ın belirleyicileri: MGARCH modelleri ile bir inceleme. Maliye Finans Yazıları, 1(84). 
[10]. Ganchev, G. T. Stavrova, E. \& Tsenkov, V. (2012). Testing the twin deficit hypothesis: The case of Central and Eastern Europe countries. International Journal of Contemporary Economics and Administrative Sciences, 2(1), 1-21.

[11]. Haug, A. A. (1990). Ricardian Equivalence, rational expectations and the permanent income hypothesis. Journal of Money, Credit and Banking, 22(3), 305-326.

[12]. Helmy, H. E. (2018). The twin deficit hypothesis in Egypt. Journal of Policy Modeling, 40(2), 328-349.

[13]. Kalou, S. \& Paleologou, S. M. (2012). The twin deficits hypothesis: Revisiting an EMU country. Journal of Policy Modeling, 34(2), 230-241.

[14]. Kaufmann, S. Scharler, J. \& Winckler, G. (2002). The Austrian current account deficit: Driven by twin deficits or by intertemporal expenditure allocation? Empirical Economics, 27(3), 529-542.

[15]. Khalid, A. M. \& Guan, T. W. (1999). Causality tests of budget and current account deficits: Cross-country comparisons. Empirical Economics, 24(3), 389-402.

[16]. Kim, C. H. \& Kim, D. (2006). Does Korea have twin deficits? Applied Economics Letters, 13(10), 675-680.

[17]. Kouassi, E. Mougoue, M. \& Kymn, K. O. (2004). Causality tests of the relationship between the twin deficits. Empirical Economics, 29(3), 503-525.

[18]. Krugman,P.R ve Obstfeld,M (2006). International Economics Theory-Policy, Seventh edition,

[19]. Mohanty, R. K. (2018). An Empirical Investigation of Twin Deficits Hypothesis: Evidence from India. Journal of Quantitative Economics, 1-23.

[20]. Parkin, Michael (2000), Economics, Fifth Edition, Addison-Wesley Publishing Company, United States.

[21]. Pattichis, C. (2004). Budget and trade deficits in Lebanon. Applied Economics Letters, 11(2), 105-108.

[22]. Pearson Addison Wesley,285-291.

[23]. Perera, A. \& Liyanage, E. (2012). An empirical investigation of the twin deficit hypothesis: Evidence from Sri Lanka. Staff Studies, 41(1).

[24]. Ravinthirakumaran, N. Selvanathan, S. \& Selvanathan, E. A. (2016). The twin deficits hypothesis in the SAARC countries: an empirical investigation. Journal of the Asia Pacific Economy, 21(1), 77-90.

[25]. Trachanas, E. \& Katrakilidis, C. (2013). The dynamic linkages of fiscal and current account deficits: New evidence from five highly indebted European countries accounting for regime shifts and asymmetries. Economic Modeling, 31, 502-510.

[26]. Turan, T. \& Karakas, M. (2018). Asymmetries In Twin Deficit Hypothesis: Evidence From Cee Countries. Ekonomický časopis (Journal of Economics), 66(6).

[27]. Vamvoukas, G. A. (1999). The twin deficits phenomenon: evidence from Greece. Applied economics, 31(9), 1093-1100.

[28]. Winner, L. E. (1993). The relationship of the current account balance and the budget balance. The American Economist, 37(2), 78-84.

[29]. Xie, Z. \& Chen, S. W. (2014). Untangling the causal relationship between government budget and current account deficits in OECD countries: Evidence from bootstrap panel Granger causality. International Review of Economics \& Finance, 31, 95-104.

[30]. Zietz, J. \& Pemberton, D. K. (1990). The US budget and trade deficits: a simultaneous equation model. Southern Economic Journal, 23-34. 